\title{
PEMANFAATAN MEDIA SOSIAL SEBAGAI MEDIA PENDIDIKAN AGAMA HINDU
}

\author{
I Gede Dharman Gunawan
}

Institut Agama Hindu Negeri Tampung Penyang Palangkaraya

bawiayahfda@gmail.com

\section{Riwayat Jurnal - \\ Artikel diterima $\quad:-$ \\ Artikel direvisi : : \\ Artikel disetujui : :-}

\begin{abstract}
Abstrak
Dewasa ini perkembangan teknologi internet telah merambah berbagai disiplin ilmu. Dengan berkembangnya teknologi internet, dunia pendidikan pun makin ramah dengan situs jejaring media sosial facebook, blogger, instagram, hingga twitter. Situs jejaring media sosial tidak hanya digunakan untuk berinteraksi dengan sesama teman. Ada yang memanfaatkannya sebagai media menyampaikan informasi, untuk mempromosikan produk, bahkan hanya sekedar untuk mencurahkan isi hati pengguna, tentunya dapat dimanfaatkan sebagai media pembelajaran yang inovatif. Berkaitan dengan permasalahan saat ini mengenai pemanfaatan media sosial yang tidak terkontrol, sehingga perlunya pemanfaatan media sosial sebagai media pembelajaran pendidikan agama Hindu yang inovatif. Tentunya pemanfaatan media sosial dapat menumbuhkan pembelajaran yang aktif, kreatif, efektif dan menyenangkan. Maka sangat penting pemanfaatan media sosial sebagai media pembelajaran pendidikan agama Hindu pada siswa.
\end{abstract}

Kata Kunci : Pemanfaatan, Media Sosial, Media Pendidikan Agama Hindu

\section{Pendahuluan}

Perkembangan ilmu pengetahuan dan teknologi berpengaruh luas ke berbagai bidang kehidupan, termasuk bidang pendidikan. Pendidikan tidak antipati atau alergi terhadap perkembangan ilmu pengetahuan dan teknologi, namun sebaliknya sebagai subyek atau pelopor dalam pengembangannya. Penggunaan teknologi dalam dunia pendidikan, khususnya dalam pembelajaran di kelas masih kurang optimal. Masih banyak dalam proses pembelajaran bersifat konvensional, sehingga pembelajaran kurang efektif dan membosankan. Kondisi tersebut sangat disayangkan karena pemanfaatan teknologi sudah seharusnya dilakukan untuk meningkatkan mutu pendidikan. Seiring dengan kemajuan teknologi, dunia pendidikan khususnya sekolah harus mau mengadakan inovasi yang positif untuk kemajuan pendidikan. Inovasi yang 
diharapkan adalah inovasi yang menyeluruh dalam setiap kegiatan pendidikan. Karena pendidikan di sekolah adalah gerbang utama sebelum mereka ke perguruan tinggi atau terjun ke masyarakat.

Perkembangan teknologi

informasi yang sangat pesat dewasa ini, khususnya perkembangan teknologi internet turut mendorong berkembangnya konsep pembelajaran jarak jauh. Ciri teknologi internet yang selalu dapat diakses kapan saja, dimana saja, multiuser, serta menawarkan segala kemudahannya telah menjadikan internet suatu media yang sangat tepat bagi perkembangan pendidikan (Uno, 2012:38).

Pradigma pemikiran manusia yang semakin kritis dan kemajuan ilmu pengetahuan teknologi dan informasi yang semakin pesat, menuntut seseorang untuk memanfaatkan teknologi tersebut dengan cepat. Dengan demikikan, dibutuhkan sumber daya manusia yang berkualitas dan bernalar tinggi serta memiliki kemampuan untuk mengaktualisasikan teknologi yang ada. Teknologi yang baik adalah teknologi yang dapat dimanfaatkan secara oftimal oleh masyarakat. Namun, untuk mempelajari, mengembangkan dan mengaktualisasikan teknologi tersebut diperlukan filterisasi yang baik sehingga berjalan dengan baik dan tidak melenceng dari sasaran yang benar. Untuk itu, diperlukan kecerdasan manusia untuk mengelola, baik kecerdasan intelektual (intelektual question), kecerdasan emosional (emotional question), dan kecerdasan spritual (spritual question). Dalam hal ini, tidak hanya kecerdasan intelektual yang diharapkan, namun tidak kalah penting yaitu kecerdasan emosional dan kecerdasan spritual. Kecerdasan emosional dan kecerdasan spritual didapatkan dari pendidikan agama yang baik, namun pendidikan agama yang terbuka dan menerima perkembangan jaman yang semakin mengglobal ini. Pendidikan agama tidak alergi dengan teknologi, namun bersama-sama bersatu padu membangun masyarakat. Karena ilmu tanpa agama adalah lumpuh, agama tanpa ilmu adalah pincang. Ilmu pengetahuan dan teknologi tersebut dapat diaktualisasikan dengan efektif, jika sudah difilterasi dengan pendidikan agama yang baik. Baik dirumah, disekolah formal, informal, nonformal maupun dalam kehidupan lingkungan bermasyarakat.

Seiring berkembangnya teknologi internet, masyarakat pun makin ramah dengan situs jejaring media sosial facebook, blogger, instagram, hingga twitter. Situs jejaring media sosial tidak hanya digunakan untuk berinteraksi dengan teman. Ada yang memanfaatkannya sebagai media menyampaikan informasi, untuk mempromosikan produk, bahkan hanya sekedar untuk mencurahkan isi hati pengguna, tentunya dapat dimanfaatkan sebagai media pembelajaran yang inovatif.

Pendidik (guru) hendaknya mampu berperan sebagai pembimbing 
untuk menuntun peserta didik (siswa) melalui proses belajar, memimpin peserta didik agar aktifitas dan minat belajar sesuai dengan tujuan pembelajaran, serta sebagai fasilitator dalam mempersiapkan kondisi yang memungkinkan siswa untuk melakukan kegiatan belajar. Guru dapat melakukan dengan pemilihan metode pembelajaran yang sesuai dengan karakteristik materi pendidikan agama Hindu yang diajarkan dan karakteristik pembelajar, memilih media pembelajaran yang relevan serta memilih strategi yang tepat dalam mengimplementasikan pembelajaran pendidikan agama Hindu di kelas.

Materi pelajaran pendidikan agama Hindu yang diajarkan dikelas begitu komplek, menyebabkan tidak dapat ditampung dan dijabarkan atau disampaikan seluruhnya didalam kelas dalam waktu yang sangat terbatas. Oleh karena itu diperlukan suatu metode yang dapat mengantarkan peserta didik belajar secara mandiri, penuh motivasi dan minat yang tinggi. Sehingga pembelajaran agama Hindu menjadi pembelajaran yang aktif, inovatif, kreatif, efektif dan menyenangkan bagi semua komponen, baik bagi peserta didik maupun pendidik dalam hal ini guru. Harapan tumbuhnya sifat kreatif dan inovatif para pendidik pendidikan agama Hindu dalam praktek pembelajaran untuk pemahaman dewasa ini masih belum optimal. Hal ini tampak dari pelaksanaan pembelajaran yang tidak lebih dari kegiatan pembelajaran yang bersifat regular dan masih bersifat konvensional atau berpusat pada guru (teacher centered) sehingga belum menyentuh peserta didik itu sendiri. Selain itu proses pembelajaran hanya bersifat menghabiskan materi sesuai dengan tuntutan kurikulum.

Dalam setiap proses pembelajaran menuntut pencapaian tujuan tertentu. Setiap tujuan memerlukan suatu metode dan srategi pembelajaran untuk menciptakan situasi belajar tertentu. Dalam suatu proses pembelajaran, tidak ada suatu metode dan strategi maupun media pembelajaran yang paling baik diantara yang lainnya, karena masingmasing metode dan srategi serta media pembelajaran dapat dirasakan baik, apabila telah diujicobakan untuk mengajarkan materi pelajaran tertentu. Dalam tiap-tiap metode dan srategi maupun media pembelajaran membutuhkan sistem pengelolaan dan lingkungan belajar yang sedikit berbeda. Oleh sebab itu pendidik hendaknya memahami metode dan strategi yang tepat sesuai dengan materi yang diajarkan serta menguasai dan mampu menerapkan media pembelajaran tersebut dengan tetap mempertimbangkan tingkat perkembangan kognitif siswa, dan sarana atau fasilitas yang ada, sehingga tujuan dapat tercapai (Arends, dalam Trianto, 2007:9).

Banyak faktor yang mempengaruhi pembelajaran di kelas, salah satunya adalah faktor proses. faktor proses merupakan inti dari pendidikan formal disekolah yang didalamnya terjadi interaksi berbagai komponen pengajaran. Komponen-komponen itu dapat 
dikelompokkan dalam tiga kategori utama yaitu: pendidik, isi atau materi, dan peserta didik. Ketiga komponen tersebut berinteraksi melibatkan sarana prasarana seperti : media pembelajaran dan lingkungan tempat belajar, sehingga tercipta situasi belajar mengajar yang memungkinkan tercapainya tujuan yang telah direncanakan sebelumnya.

Perkembangan media sosial yang semakin hari semakin pesat terjadi, telah membawa manusia pada titik dimana tidak bisa lepas dari penggunaan media sosial dalam kehidupan sehari-hari. Teknologi pun saat ini telah memberikan kemudahan bagi setiap manusia untuk tetap selalu terhubung kepada setiap orang diberbagai belahan dunia. Kemudahan dalam berkomunikasi saat ini semakin terasa kental di kalangan siswa. Facebook, Twitter, BBM, dan lain sebagainya seperti sudah menjadi trend tersendiri dikalangan para remaja. Berbagai macam media sosial tersebut tentunya dapat menjadi media pembelajaran yang kreatif dan inovatif yang dapat diakses oleh setiap siswa. Namun dalam proses pembelajaran pendidikan agama Hindu perlu dioptimalkan melalui pemanfaatan media sosial sebagai media pembelajaran oleh guru dan siswa.

\section{Pembahasan}

\subsection{Pemanfaatan Media Pendidikan Agama Hindu}

Pemanfaatan merupakan turunan

kata dari kata 'Manfaat', yakni suatu penghadapan yang semata-mata menunjukan kegiatan menerima. Penghadapan tersebut pada umumnya mengarah pada perolehan atau pemakaian yang hal-hal yang berguna baik di pergunakan secara langsung maupun tidak langsung agar dapat bermanfaat. Pemanfaatan adalah hal, cara, hasil kerja dalam memanfaatkan sesuatu yang berguna. Acapkali kata media pendidikan digunakan secara bergantian dengan istilah alat bantu atau media komunikasi dimana hubungan komunikasi akan berjalan lancar dengan hasil yang maksimal apabila menggunakan alat bantu yang disebut media komunikasi. Menurut Munir (2008) media pembelajaran dapat diartikan sebagai perantara sampainya pesan belajar (massage learning) dari sumber pesan (massage resource) kepada penerima pesan (massage receive), sehingga terjadi interaksi belajar mengajar. Media adalah mode stimulusinteraksi manusia, realita yang salah satunya berupa media yang inovatif.

Media sebagai perantara yang mengantar informasi antar sumber dengan penerima. Jadi, televisi, film, radio, rekaman audio, gambar yang 
diproyeksikan, audiovisual, bahan-bahan cetakan, dan sejenisnya adalah media komunikasi. Apabila media itu membawa pesan-pesan atau informasi yang bertujuan instruksional atau mengandung maksud-maksud pengajaran maka media itu disebut media pembelajaran. sejalan dengan batasan ini, Hamidjojo dan Latuheru (1993) memberi batasan media sebagai semua bentuk perantara yang digunakan oleh manusia untuk menyampaikan atau menyebar ide, gagasan atau pendapat, sehingga ide atau pendapat yang dikemukakan itu sampai pada penerima yang dituju.

Mayer (2009) dalam bukunya Multimedia Learning mengatakan bahwa, belajar melalui multimedia, siswa dapat menciptakan pemahaman lebih dalam dari sekedar belajar dari kata-kata saja atau gambar-gambar saja. pembelajaran dengan mempergunakan multimedia dengan menampilkan gambar, suara (audiovisual) akan meningkatkan aktifitas pembelajaran di kelas dan pembelajaran pasti akan lebih bermakna.

Media pembelajaran khususnya yang bersentuhan dengan teknologi mempunyai peranan yang sangat penting dalam proses pembelajaran. dengan media ini, proses pembelajaran akan lebih menyenangkan, tidak membosankan dan menjadi pilihan tepat bagi para pendidik. Kerumitan dan ketidak jelasan materi dapat dibantu dengan menghadirkan media yang inovatif.

Kata media berasal dari bahasa latin medius yang secara harfiah berarti 'tengah', 'perantara', atau 'pengantar'. Dalam bahasa Arab, media adalah perantara atau pengantar pesan dari pengirim kepada penerima pesan. Gerlach \& Ely (1971) dalam Arsyad (2006) mengatakan bahwa media apabila dipahami secara garis besar adalah manusia, materi, atau kejadian yang membangun kondisi yang membuat siswa mampu memproleh pengetahuan, ketrampilan atau sikap. Dalam pengertian ini, guru, buku teks, dan lingkungan sekolah merupakan media. Secara lebih khusus, pengertian media dalam proses belajar mengajar cendrung diartikan sebagai alat-alat grafis, fotografis, atau elektronik untuk menangkap, memproses dan menyusun kembali informasi visual dan verbal.

Batasan lain telah pula dikemukakan oleh para ahli yang sebagian diantaranya seperti AECT 
(Association of Education an Communication Teknology, 1977) memberi batasan tentang media sebagai suatu bentuk dan saluran yang digunakan untuk menyampaikan pesan atau informasi. Disamping sebagai sistem penyampai atau pengantar, media yang sering diganti dengan kata mediator. Dengan istilah mediator media menunjukan fungsi atau perannya, yaitu mengatur hubungan yang efektif antara dua pihak utama dalam proses belajar siswa dan isi pelajaran. Disamping itu mediator juga dapat mencerminkan pengertian bahwa setiap sistem pembelajaran yang melakukan peran mediasi, mulai dari guru sampai peralatan paling canggih, dapat disebut media. Ringkasnya, media adalah alat yang menyampaikan atau mengantarkan pesanpesan pembelajaran.

Bertolak dari pengertian di atas, maka dapatlah dikatakan Media pendidikan Agama Hindu ini adalah suatu alat yang menyampaikan atau mengantarkan pesan-pesan pembelajaran pendidikan melalui ajaran Agama Hindu, dengan tujuan untuk meningkatkan sraddha dan bhakti anak terhadap Ida Sang Hyang widhi Wasa (Tuhan Yang
Maha Esa), meningkatkan kecerdasan ketrampilan dalam menjalankan ajaran agama, mempertinggi budi pekerti, memperkuat kepribadian, mempertebal semangat kebangsaan dan cinta tanah air.

\subsection{Media Sosial Sebagai Media Pendidikan Agama Hindu}

Media sosial adalah sebuah media online, dengan para penggunanya bisa dengan mudah berpartisipasi, berbagi, dan menciptakan isi meliputi facebook, twitter, blog, wiki, forum dan dunia virtual. Blog, jejaring sosial dan wiki merupakan bentuk media sosial yang paling umum digunakan oleh masyarakat di seluruh dunia.

Menurut Andreas Kaplan dan Michael Haenlein (2010), media sosial adalah sebuah kelompok aplikasi berbasis Internet yang dibangun diatas dasar ideologi dan teknologi Web 2.0 dan yang memungkinkan penciptaan dan pertukaran user-generated content. Jadi, yang dimaksud user-generated content adalah segala isi yang dibuat dan atau dipublikasikan oleh pengguna media siber antara lain, artikel, gambar, komentar, suara, video dan berbagai bentuk unggahan yang melekat pada media siber, 
seperti blog, forum, komentar pembaca atau pemirsa, dan bentuk lain.

Media sosial memiliki kelebihan dibandingkan dengan media konvensional, antara lain :

a. Kesederhanaan

Dalam sebuah produksi media konvensional dibutuhkan keterampilan tingkat tinggi dan keterampilan marketing yang unggul. Sedangkan media sosial sangat mudah digunakan, bahkan untuk orang tanpa dasar TI pun dapat mengaksesnya, yang dibutuhkan hanyalah komputer dan koneksi internet.

b. Membangun Hubungan

Sosial media menawarkan kesempatan tak tertandingi untuk berinteraksi dengan pelanggan dan membangun hubungan. Perusahaan mendapatkan sebuah feedback langsung, ide, pengujian dan mengelola layanan pelanggan dengan cepat. Tidak dengan media tradisional yang tidak dapat melakukan hal tersebut, media tradisional hanya melakukan komunikasi satu arah.

c. Jangkauan Global

Media tradisional dapat menjangkau secara global tetapi tentu saja dengan biaya sangat mahal dan memakan waktu. Melalui media sosial, bisnis dapat mengkomunikasikan informasi dalam sekejap, terlepas dari lokasi geografis. Media sosial juga memungkinkan untuk menyesuaikan konten anda untuk setiap segmen pasar dan memberikan kesempatan bisnis untuk mengirimkan pesan ke lebih banyak pengguna.

d. Terukur

Dengan sistemtracking yang mudah, pengiriman pesan dapat terukur, sehingga perusahaan langsung dapat mengetahui efektifitas promosi. Tidak demikian dengan media konvensional yang membutuhkan waktu yang lama.

Ketika kita mendefinisikan media sosial sebagai sistem komunikasi maka kita harus mendefinisikan fungsi-fungsi terkait dengan sistem komunikasi, Adapun fungsi sosial media yaitu :

a. Administrasi

Pengorganisasian proofil karyawan perusahaan dalam jaringan sosial yang relevan dan relatif dimana posisi pasar anda sekarang. Pembentukan pelatihan kebijakan media sosial, dan pendidikan untuk semua karyawan pada penggunaan media sosial. Pembentukan sebuah blog organisasi dan integrasi konten dalam masyarakat yang 
relevan. Riset pasatr untuk menemukan dimana pasar anda.

b. Mendengarkan dan Belajar

Pembuatan sistem pemantauan untuk mendengar apa yang pasar anda inginkan, apa yang relevan dengan mereka.

c. Berpikir dan Perencanaan

Dengan melihat tahap 1 dan 2, bagaiman anda akan tetap didepan pasar dan begaiman anda berkomunikasi ke pasar. Bagaiman teknologi sosial meningkatkan efisiensi operasional hubungan pasar.

d. Pengukuran

Menetapkan langkah-langkah efektif sangat penting untuk mengukur apakah metode yang digunakan, isi dibuat dan alat yang anda gunakan efektif dalam meningkatkan posisi dan hubungan pasar anda.

Jejaring sosial media juga ada dampak positif dan dampak negatif yang sangat berpengaruh pada kehidupan manusia. Pertama kita akan mengawalinya dengan dampak negatif dari sosial media terlebih dahulu.

a. Dampak Negatif

1. Kecanduan situs jejaring sosial seperti Facebook atau MySpace juga bisa membahayakan kesehatan karena memicu orang untuk mengisolasikan diri. Meningkatnya pengisolasian diri dapat mengubah cara kerja gen, membingungkan respons kekebalan, level hormon, fungsi urat nadi, dan merusak performa mental.

2. Seseorang yang menghabiskan waktunya di depan komputer akan jarang berolahraga sehingga kecanduan aktivitas ini dapat menimbulkan kondisi fisik yang lemah, bahkan obesitas.

3. Kerusakan fisik juga sangat mungkin terjadi. Bila menggunakan mouse atau memencet keypad ponsel selama berjam-jam setiap hari, seseorang dapat mengalami cedera tekanan yang berulang-ulang. Penyakit punggung juga merupakan hal yang umum terjadi, pada orang-orang yang menghabiskan banyak waktu duduk di depan meja komputer.

4. Media elektronik, seperti komputer, laptop, atau handphone (ponsel) juga menghancurkan secara perlahan-lahan kemampuan anak-anak dan kalangan dewasa muda untuk mempelajari kemampuan sosial dan membaca bahasa tubuh. Maksudnya adalah 
seseorang akan mengalami pengurangan interaksi dengan sesama mereka dalam jumlah menit per harinya menyebabkan jumlah orang yang tidak dapat diajak berdiskusi mengenai masalah penting, menjadi semakin meningkat setiap harinya.

5. Kejahatan dunia maya (cyber crime). Seiring berkembangnya teknologi, berkembang pula kejahatan. Di dunia internet, kejahatan dikenal dengan nama cyber crime. Kejahatan dunia maya sangatlah beragam. Diantaranya, carding, hacking, cracking, phising, dan spamming.

6. Membuat waktu terbuang dengan sia-sia

b. Dampak Positif

1. Sebagai media penyebaran informasi

$$
\text { Informasi yang up to date }
$$
sangat mudah menyebar melalui situs jejaring sosial. Hanya dalam tempo beberapa menit setelah kejadian, kita telah bisa menikmati informasi tersebut. Ini sangatlah bermanfaat bagi kita sebagai manusia yang hidup di era digital seperti sekarang ini. Cakrawala dunia serasa berada dalam sentuhan jari kita.

2. Sebagai sarana untuk mengembangkan keterampilan dan sosial

Mengasah keterampilan teknis dan sosial merupakan kebutuhan yang wajib dipenuhi agar bisa bertahan hidup dan berada dalam neraca persaingan diera modern seperti sekarang ini Hal ini sangatlah penting, tidak ada batasan usia, semua orang butuh untuk berkembang.

3. Memperluas jaringan pertemanan Dengan menggunakan jejaring sosial, kita bisa berkomunikasi dengan siapa saja, bahkan dengan orang yang belum kita kenal sekalipun dari berbagai penjuru dunia. Kelebihan ini bisa kita manfaatkan untuk menambah wawasan, bertukar pikiran, saling mengenal budaya dan ciri khas daerah masing-masing, dll. Hal ini dapat pula mengasah kemampuan berbahasa seseorang. Misalnya, belajar bahasa inggris dengan memanfaatkan fasilitas call atau video call yang disediakan di situs jejaring sosial.

Media sosial menjadi bermanfaat dan saluran komunikasi yang semakin 
penting karena meningkatnya penggunaan media sosial sebagai situs berita dan informasi oleh banyak orang, penggunaan terhadap media sosial di kalangan masyarakat sebagai penyebarluasan berita dan informasi melalui media sosial, juga sebagai media pembelajaran. Terkadang pemanfaatan media sosial sebagai media pembelajaran memiliki dampak yang negatif. Untuk mensiasati permasalah dampak negatif media sosial, sebaiknya guru agama Hindu memanfaatkan media sosial untuk pembelajaran pendidikan agama Hindu. Caranya adalah sebagai berikut :

1. Membuat materi pelajaran yang sedang diajarkan di sekolah. Dengan cara ini siswa yang memiliki akun media sosial bisa mendapatkan pengetahuan atau ilmu dari media sosial yang kini bisa diakses dimana saja dan kapan saja melalui handphone, tablet atau komputer pribadi.

2. Membuat soal latihan di media sosial seperti facebook, siswa diharapkan menjawab pertanyaan tersebut melalui pesan di inbox atau melalui komentar yang ada di bawah soal latihan tersebut. Tidak masalah siswa copy paste jawaban dari orang lain, tetapi minimal siswa sudah membaca soal tersebut.
3. Mencantumkan link soal latihan di media sosial yang mengarah ke blog guru mata pelajaran. Sehingga selain siswa bisa belajar tentang materi soal pelajaran, blog guru tersebut juga akan kebanjiran pengunjung yang tidak lain adalah para siswanya sendiri.

Dengan cara seperti itu siswa akan dituntun untuk menggunakan media sosial sebagai sarana pembelajaran mata pelajaran agama Hindu, dan guru bisa memperhatikan gerak-gerik siswa dan siswi kita di media sosial. Apakah mereka menulis atau mengunggah hal-hal yang positif atau negatif. Dalam pemanfaatan media sosial sebagai media pembelajaran pendidikan agama Hindu, guru agama Hindu juga dapat memanfaatkan penggunaan blog. Blog dapat dimaanfaatkan sebagai media pembelajaran untuk setiap orang. Blogger merupakan situs jejaring sosial yang berupa teks dokumen, gambar, obyek media, dan data yang tersusun secara rapi yang dapat dilihat melalui browser internet dan biasanya berisi catatan atau jurnal pribadi. Manfaat blog yaitu, 1) Media interaktif di luar kelas. Misalnya guru disebuah sekolah memposting materi pelajaran. Kemudian 
siswa mengakses blog tersebut, siswa mengisi komen di blog lalu guru menanggapinya, sehingga terjadi komunikasi antara guru dengan siswa. 2) Media untuk menyimpan file. Guru dapat menyusun dan meresume materi pelajaran kemudian meng-updatenya ke blog. Dengan begitu, siswa dapat belajar kapan saja tanpa dibatasi waktu dan tempat. 3) Media untuk mendapatkan informasi. Guru dan siswa bisa mendapatkan informasi melalui proses pencarian dengan search engine akan membuka dan menambah wawasan guru dan siswa tentang dunianya dan dunia ilmu pengetahuan. Bisa melalui membaca koran, buku, majalah namun kita hanya berperan sebagai pembaca pasif. Dan masih banyak lagi pemanfaatan blog sebagai media pembelajaran terutamanya dalam pembelajaran pendidikan agama Hindu.

\subsection{Penutup}

Pemanfaatan media sosial sebagai media pembelajaran pendidikan agama Hindu dapat meningkatnya kualitas pembelajaran pendidikan agama Hindu, dimana pembelajaran pendidikan agama Hindu dapat berorientasi pada media pembelajaran berbasis online yang inovatif. Tersedianya media pembelajaran pendidikan agama Hindu alternatif yang berbasis pada media sosial (online) untuk pengajaran pendidikan agama Hindu dapat memberikan kemudahan kepada guru pendidikan agama Hindu dalam melaksakan proses pembelajaran dengan menerapkan media pembelajaran berbasis online yakni media sosial. Memperluas wawasan pengetahuan guru agama Hindu tentang mengajar dengan media pembelajaran berbasis online. Pemanfaatan media sosial sebagai media pendidikan agama Hindu adalah memberi imbas dengan landasan yang mendasar bagi guru pendidikan agama Hindu untuk memilih metode serta media pembelajaran yang inovatif yang sesuai dengan tuntutan pendidikan saat ini.

Dalam pemanfaatan media sosial seperti pemanfaatan blog sebagai media pendidikan agama Hindu guru mata pelajaran agama Hindu, dapat mengembangkan media sehingga tujuan pembelajaran agama Hindu dapat tercapai dengan baik. Peserta didik pun dapat meningkatkan minat, kreatifitas, gairah dan motivasi belajar mereka dengan cara melatih diri bertanggung jawab pada diri dan lingkungan sekitarnya. Serta 
diharapkan menghasilkan peserta didik yang aktif dan dapat menemukan cara belajar yang sesuai.

\section{Daftar Pustaka}

Arsyad, Azhar. 2007. Media Pembelajaran. Jakarta : Raja Grafindo Persada.

Burhan Bungin. 2008. Konstruksi Sosial Media Massa. Jakarta : Kencana.

Danesi, Marcel. 2010. Pengantar Memahami Semiotika Media. Yogyakarta : Jalasutra.

Danim, Sudarwan. 2008. Media Komunikasi Pendidikan : Pelayanan Profesional Pembelajaran Dan Mutu Hasil Belajar. Jakarta : Bumi Aksara.

Deddy Mulyana. 2011. Media dan Perubahan Sosial. Bandung : Remaja Rosdakarya.

Kustandi, Cecep dan Sutjipto, Bambang. 2011. Media Pembelajaran : Manual dan Digital. Bogor : Ghalia Indonesia.

Sadiman, Arief S. dkk. 2009. Media Pendidikan : Pengertian, Pengembangan dan Pemanfaatannya. Jakarta : Rajawali Pers.

Sukiman. 2012. Pengambangan Media Pembelajaran. Yogyakarta : Pedagogia.

Uno, Hamzah. 2012. Model pembelajaran Menciptakan Proses Belajar Mengajar Yang Kreatif Dan Efektif. Jakarta : Bumi Aksara. 